\title{
MODEL FUNGSIONALISASI NILAI-NILAI KEARIFAN LOKAL (LOCAL GENIUS) DALAM KEBIJAKAN HUKUM (LEGAL POLICY) DAERAH DI PROVINSI JAWA TENGAH (Kajian Konstitusional Penguatan Komunitas Adat Sedulur Sikep Pati dalam Pengelolaan SDA \& Pelestarian LH)
}

\author{
Budiyanto \\ Kesbangpolinmas Provinsi Jawa Tengah \\ yantostonen@gmail.com
}

\begin{abstract}
This study aimed to describe the functional model of the values of local wisdom in the policy area corresponding legal ideals (rechtsideee) of Pancasila. Socio-legal research approach based on constructivism legal paradigm was used to identify the local wisdom Sedulur Sikep and legal policies concerning the construction of Semen Gresik in Sukolilo Pati. The results showed that Sedulur Sikep an indigenous community in the mountains Kendeng who believes that the earth is a biological mother who gives living (hangrungkebi bumi pertiwi), so shall behave harmoniously with its natural surroundings (hamemayu hayuning bawana). Local wisdom of Sedulur Sikep rests on three main values in life (humanity), namely fairness, honesty and truthfulness (propriety) as basis of the rejection of legal policy establishment Semen Gresik in Sukolilo Pati. Therefore, the legal policy areas should be able to accommodate the values of local genius in order to give recognition, respect and protection of the whole of the community customary law in the legal system of the country. The study recommends the concept of "The Law-Society Integrative Framework" as a model for the functionalization of the values of local genius in legal policy areas in the field of natural resource management and environmental conservation. This model is the concept of legal policy futuristic reformative legal foundations by considering the values of local genius is still alive, so as to strengthen the fundamentals of democratic economic environment (ecological), nuanced legitimatif democratic, integrative and social recovery function (social recuperation).
\end{abstract}

Keywords: Model functionalizing, Local Wisdom, Legal Policy, Sedulur Sikep.

\begin{abstract}
Abstrak
Penelitian ini concern untuk mendeskripsikan model fungsionalisasi nilai-nilai kearifan lokal dalam kebijakan daerah sesuai cita hukum Pancasila. Pendekatan socio-legal research berdasarkan paradigma legal constructivism digunakan untuk mengidentifikasi kearifan lokal Sedulur Sikep Sukolilo Pati dan kebijakan hukum pembangunan Pabrik Semen Gresik. Hasil penelitian menunjukkan bahwa Sedulur Sikep merupakan komunitas masyarakat adat di pegunungan Kendeng yang meyakini bahwa bumi adalah sebagai ibu kandung yang memberi penghidupan (hangrungkebi bumi pertiwi), sehingga wajib berperilaku harmonis dengan alam sekitarnya (hamemayu hayuning bawana). Kearifan lokal Sedulur Sikep bertumpu pada tiga nilai utama dalam kehidupan (kemanusiaan), yakni keadilan, kejujuran dan kebenaran (kepatutan) menjadi dasar penolakan terhadap kebijakan hukum pendirian Pabrik Semen Gresik di Sukolilo Pati. Oleh karena itu, kebijakan hukum daerah harus dapat mengakomodasi nilai-nilai kearifan lokal agar dapat memberikan pengakuan, penghormatan \& perlindungan yang utuh terhadap masyarakat hukum adat dalam sistem hukum negara. Studi ini merekomendasikan konsep"The Integratif Law-Society Framework" sebagai model fungsionalisasi nilai-nilai kearifan lokal dalam kebijakan
\end{abstract}


hukum daerah di bidang pengelolaan sumberdaya alam dan pelestarian lingkungan hidup. Model ini merupakan konsep kebijakan hukum reformatif yang bersifat legal futuristic dengan mempertimbangkan nilai-nilai kearifan lokal yang masih hidup, sehingga dapat memperkuat fundamen ekonomi kerakyatan yang berwawasan lingkungan (ekologis), bernuansa demokratis legitimatif, integratif dan berfungsi pemulihan sosial (social recuperation).

Kata Kunci: Model Fungsionalisasi, Kearifan Lokal, Kebijakan Hukum, Sedulur Sikep.

\section{A. Pendahuluan}

Eksistensi hukum adat di Indonesia sampai saat ini telah diakui secara konstitusional. Sebagaimana tertuang dalam Pasal $18 \mathrm{~B}$ ayat (2) Undang-Undang Dasar 1945 yang menyatakan bahwa "Negara mengakui dan menghormati kesatuan-kesatuan masyarakat hukum adat beserta hak-hak tradisionalnya sepanjang masih hidup dan sesuai dengan perkembangan dan prinsip Negara Kesatuan Republik Indonesia yang diatur dalam undang-undang". Selanjutnya dalam Pasal 28l ayat (3) Undang-Undang Dasar 1945 dinyatakan bahwa identitas budaya dan hak masyarakat tradisional dihormati selaras dengan perkembangan jaman dan peradaban. Dalam berbagai undang-undang juga disinggung mengenai eksistensi hukum adat dan masyarakat adat, antara lain dalam Pasal 6 ayat (1) dan ayat (2) UU No. 39/1999 tentang Hak Asasi Manusia; UU No. 5/1994 tentang pengesahan Konvensi PBB tentang Keanekaragaman Hayati yang memuat prinsip free and prior inform consent; UU No. 32/2004 tentang Pemerintah Daerah (UU Pemda) yang mengatur prinsip desentralisasi dalam pengelolaan sumberdaya alam (SDA) dan lingkungan hidup (LH); dan Pasal 1 ayat (30) UU No. 32/2009 tentang Perlindungan dan Pengelolaan Lingkungan Hidup (UUPPLH).

Pasal 33 ayat (1) UUD NRI 1945 telah mengamanatkan bahwa "Bumi, dan air dan kekayaan alam yang terkandung di dalamnya dikuasai oleh negara dan dipergunakan untuk sebesar-besar kemakmuran rakyat". Pengertian sebesar-besarnya kemakmuran rakyat menunjukkan bahwa rakyat harus menerima manfaat dari SDA dan LH yang ada di Indonesia. Negara mempunyai kewajiban untuk mengatur SDA agar dimanfaatkan untuk meningkatkan kesejahteraan rakyat dan mencapai kebahagiaan hidup yang berdasarkan Pancasila. Namun demikian, pengamatan sosiologis menunjukkan bahwa politik kebijakan pengelolaan SDA dan pelestarian LH yang dilakukan oleh otoritas penguasa terkadang melahirkan kebijakan yang mengabaikan kearifan lokal masyarakat adat. "Supremacy of law" dapat menimbulkan ketidakadilan bahkan juga ketidakpastian dalam upaya mencapai keadilan yang substantif. Satu contoh kasus yang dapat dikemukakan di sini misalnya kearifan lokal masyarakat Sedulur Sikep di Pegunungan Kendeng Utara Sukolilo Pati yang terusik karena pemerintah akan mendirikan pabrik Semen Gresik. Penolakan warga ini di latarbelakangi oleh pandangan hidup yang dikenal dengan Ajaran Samin (Sikep).

Masyarakat Sedulur Sikep dengan budaya hukumnya mempunyai nilai, sikap, customary serta way of thingking. ${ }^{1}$ Masyarakat Sedulur Sikep cenderung menjadi lebih apatis, skeptis, karena peraturan yang bersifat tertulis, mengikat, umum dan statis, lebih bersifat top down, ${ }^{2}$ bahkan memberikan peluang bagi kegiatan industrialisasi dan bisnis melalui hukum nasional, yang cara kerjanya disemangati oleh nilai kapitalisme. ${ }^{3}$ Benturan peraturan dan keadaan masyarakat Sedulur Sikep dapat digolongkan dalam beban budaya yang tertekan, akibat terjadinya benturan antara aturan masyarakat (society regularies) dengan hukum negara (state law). ${ }^{4}$ Ada celah

1 Geertz, Clifford, 1983, Local Knowledge: Further Essay in Interperatif Anthropolgy, Basic Books, New York, hlm. 17-18.

2 Sutrisno, Lukman, 1989, Masalah dan Proyek PIRBUN, Dalam Prisma No. 4 Tahun XVIII, LP3ES, Jakarta, hlm. 29.

3 Rahardjo, Satjipto, 2000, Pembangunan Hukum di Indonesia dalam konteks Situasi Global, Dalam Khudfaizah Dimyati (Penyunting), Problema Globalisasi Perspektif Sosiologi Hukum, Ekonomi dan Agama, Muhammadiyah Press, Surakarta, hlm. 6.

4 Sidharta, Bernard Arif, 1989, Refleksi tentang Struktur IImu Hukum; Sebuah Penelitian tentang Fondasi Kefilsafatan dan Sifat Keilmuan IImu Hukum sebagai Landasan Pengembangan IImu Hukum Nasional Indonesia, Mandar Maju, Bandung, hlm. 66. 
selisih yang menganga besar (legal gaps) antara intensi para penguasa pembuat kebijakan hukum (law making institution) itu dengan realitas yang ada di alam kesadaran masyarakat Sedulur Sikep tentang apa yang harus disebut hukum yang adil dan apa yang bukan hukum menurut persepsi dan konsepsi rakyat. Fakta tersebut membutuhkan tindakan komunikatif yang lebih arif dan cerdas untuk menutup celah selisih yang lebar antara the legal realities yang ada di benak para penguasa pembuat kebijakan hukum (law making institution) yang harus ditegakkan itu dengan legal realities yang ada di alam kesadaran masyarakat. Dua kutub realitas yang berada di alam kesadaran yang berbeda, tentang 'apa yang sesungguhnya harus dibilangkan sebagai hukum' yang harus diupayakan signifikansi sosialnya', dengan demikian akan dapat lebih didekatkan.

Fakta-fakta inilah yang menandai urgennya studi ini dilakukan, sekaligus menjadi konsiderasi melakukan studi berjudul "Model Fungsionalisasi Nilai-Nilai Kearifan Lokal (Local Genius) Dalam Kebijakan Hukum (Legal Policy) Daerah Di Provinsi Jawa Tengah (Kajian Konstitusional Penguatan Komunitas Adat Sedulur Sikep Pati dalam Pengelolaan Sumberdaya Alam dan Pelestarian Lingkungan Hidup)". Penelitian ini mengkaji norma positif dalam peraturan perundangan yang berlaku umum "in abstracto" terkait dengan pengakuan keberadaan dan hak-hak masyarakat adat (Sedulur Sikep) atas SDA dan LH. Rumusan Permasalahan dalam penelitian ini adalah:

1. Bagaimana profil wilayah komunitas Sedulur Sikep dan kebijakan hukum pendirian pabrik semen PT Semen Gresik di Sukolilo Pati?

2. Bagaimana kebijakan hukum (legal policy) daerah berbasis nilai-nilai kearifan lokal (local genius) Sedulur Sikep dalam pengelolaan SDA dan pelestarian $\mathrm{LH}$ ?

3. Bagaimana model fungsionalisasi nilainilai kearifan lokal (local genius) dalam kebijakan hukum (legal policy) di bidang pengelolaan SDA dan pelestarian $\mathrm{LH}$ sesuai dengan cita hukum Pancasila?

\section{B. Metode Penelitian}

Paradigma yang digunakan penelitian ini adalah paradigma constructivism atau legal constructivism. ${ }^{5}$ Penelitian ini merupakan penelitian hukum karena didasarkan pada metode, sistematika dan pemikiran tertentu, yang bertujuan untuk mempelajari satu atau beberapa gejala hukum tertentu, dengan jalan menganalisisnya. ${ }^{6}$ Pendekatan socio-legal research, ${ }^{7}$ dilakukan untuk memahami hukum dalam konteks, yaitu masyarakatnya. Metode hermeneutics dan dialectics, ${ }^{8}$ dipergunakan untuk mengidentifikasi kebenaran atau konstruksi pendapat dari orang perorang atau kasus instrumental (instrumental case study), dengan pola kualitatif. ${ }^{9}$

5 Paradigma yang dimaksudkan dalam studi ini ialah seperangkat keyakinan dasar sebagai 'set of believe' yang mengarahkan semua proses penelitian ini. Lihat Kuhn, Thomas, 2000, The Structure of Scientific Revolution. Terjemahan Tjun Surjaman, Remaja Rosda Karya, Bandung, hlm. 47. Bandingkan dengan Kleden, Ignas. Sikap IImiah...., Op.Cit., hlm. 20

6 Soerjono Soekanto, 2007, Pengantar Penelitian Hukum, Cet. 3, UI-Press, Jakarta, hlm. 43.

7 Pendekatan socio-legal research meliputi dua aspek penelitian, yaitu: (i) aspek legal research, yakni objek penelitian tetap ada yang berupa hukum dalam arti "norm" peraturan perundangundangan; dan (ii) aspek socio-research, yaitu digunakannya metode dan teori ilmu-ilmu sosial tentang hukum untuk membantu peneliti dalam melakukan analisis. Pendekatan ini menurut penulis tetap berada dalam ranah hukum, hanya perspektifnya yang berbeda. Bandingkan dengan pendapat Terry Hutchinson yang mengakui bahwa socio-legal research sebagai bagian dari penelitian hukum dengan istilah "Fundamental Research". Lihat Hutchinson, Terry, 2002, Researching and Wraiting in Law, Pyramont-NSW, hIm. 9-10. Istilah lainnya adalah pendekatan socio-legal studies yang melihat hukum sebagai salah satu faktor dalam sistem sosial yang dapat menentukan dan ditentukan. Ada sejumlah istilah yang digunakan untuk menggambarkan hal ini, seperti: apply social science to law, social scientific approaches to law, disciplines that apply social scientific perspective to study of law. Lihat Simarmata, Rikardo. "Socio-Legal Studies dan Gerakan Pembaharuan Hukum”, Dalam Journal of Digest Law, Society \& Development, Vol. I, Desember 2006-Maret 2007. Baca juga Arief Hidayat, Kebebasan Berserikat Di Indonesia (Suatu Analisis Pengaruh Perubahan Sistem Politik Terhadap Penafsiran Hukum), Badan Penerbit Universitas Diponegoro, Semarang, 2006, hlm. 52.

8 Lihat Wignyosoebroto, Soetandyo. "Perubahan Paradigma dalam IImu Hukum Pada Masa Peralihan Milenium: dari abad 20 ke abad 21", (Bahan Kuliah Program Doktor IImu Hukum UI, Jakarta, 2003), hlm.13.

9 Penelitian kualitatif yang mendasari pertanyaannya 
Jawaban permasalahan dan tujuan penelitian ini, memerlukan data-data kualitatif, terutama data sekunder, yang mencakup bahan hukum primer, bahan hukum sekunder, dan bahan hukum tersier. ${ }^{10}$ Bahan hukum primer meliputi: Konstitusi/UUD, Peraturan perundang-undangan (Ketetapan MPR, Undang-Undang/Perpu, Peraturan Pemerintah, Peraturan Presiden, dan peraturan perundang-undangan lainnya) yang mengatur nilai-nilai kearifan lokal dalam kebijakan hukum pengelolaan SDA dan pelestarian LH -, serta putusan pengadilan, maupun material empiris, yaitu dari arsip dokumen hukum resmi (risalah dan draft naskah akademik pembuatan regulasi daerah, program, memorandum dan kebijakan-kebijakan hukum di bidang pengelolaan SDA dan pelestarian $\mathrm{LH}$ ). Bahan hukum sekunder, yang memberikan penjelasan mengenai bahan hukum primer yaitu hasilhasil penelitian, hasil-hasil analisis peraturan perundang-undangan, buku-buku, publikasi ilmiah dan literatur lainnya yang berkaitan dengan masalah kebijakan hukum pengelolaan SDA dan pelestarian $\mathrm{LH}$ berbasis nilai-nilai kearifan lokal sesuai cita hukum Pancasila. Adapun data primer penelitian diperoleh melalui data dari lapangan, baik melalui wawancara, observasi, maupun interpretasi dokumen hukum terkait, dan personal experience. ${ }^{11}$ Sumber sekunder ini meliputi sejumlah informan pokok, yakni: Aparatur Pemprov Jawa Tengah dan Pemkab Pati, Pimpinan adat dan tokoh masyarakat komunitas Sedulur Sikep Pati dan sekitarnya,

pada how dan why, sejatinya memilih strategi studi kasus karena dimaksudkan untuk mengungkap peristiwa masa lalu dan sekaligus masa kini dan kemungkinan masa depan. Baca K.Yin, Robert. Case Study Research: Desain and Methods, Sage, London, 1981, hlm. 20. Penelitian kualitatif mempunyai empat unsur, yaitu: (i) Pengambilan/ penentuan sampel secara purposive; (ii) Analisis induktif; (iii) Grounded Theory; dan (iv) Desain sementara akan berubah sesuai dengan konteksnya. Baca Muhadjir, Noeng. Metodologi Penelitian Kualitatif, Penerbit Rake Sarasin, Yogyakarta, 2002, hlm. 165-168.

10 Soerjono Soekanto dan Sri Mamudji, 1990, Penelitian Hukum Normatif: Suatu Tinjauan Singkat, Ed.1, Cet.3, Rajawali, Jakarta, hlm. 14-15.

11 Bagong, Suyanto dan Sutinah, 2006, Metode Penelitian Sosial Berbagai Alternatif Pendekatan, Prenada Media Group, Jakarta, hlm. 186. maupun berbagai organisasi/lembaga (Asosiasi HTN-HAN, pakar hukum, LSM, dan organisasi sosial dalam masyarakat lain) yang berkaitan dengan persoalan penelitian.

Uji validitas data menggunakan teknik trianggulasi metode dan narasumber, dengan mengadakan strategi pengecekan melalui teknik pengumpulan data observasi partisipatif dan wawancara mendalam di satu pihak, dan di pihak lain melakukan diskusi, terutama dalam memperoleh data dari informan terpilih. Analisis data dilakukan secara yuridis kualitatif terhadap data sekunder untuk memperoleh jawaban dan kesimpulan terhadap permasalahan yang diteliti.

\section{Hasil Penelitian \& Pembahasan}

1. Profil Wilayah Komunitas Sedulur Sikep dan Kebijakan Hukum Pendirian Pabrik Semen Gresik Di Sukolilo Pati

Menyerasikan hubungan antara visi pembangunan (developmentalisme) dengan aspek lingkungan (ekologi) dapat dilaksanakan melalui operasionalisasi pembangunan berkelanjutan berwawasan lingkungan (ecodevelopmentalisme). ${ }^{12}$ Berkaitan dengan hal tersebut, komunitas-komunitas lokal (indigenous people) memiliki nilai-nilai kearifan lokal (local genius) yang unik dan khas bagi setiap kebudayaan atau masyarakat dalam menyelaraskan hubungannya dengan alam (SDA-LH) seperti halnya nilai kearifan lokal (local genius) yang dimiliki komunitas Sedulur Sikep di Pati. Local genius tersebut berupa nilai pengetahuan budaya (indigenous knowledge) Sedulur Sikep dalam mengelola SDA dan LH secara lestari dan berkelanjutan, ajeg secara ekologis, ekonomis dan sosial budaya, yang berlangsung tanpa mereka sadari hakikat

12 Lingkungan hidup dengan sumber-sumberdayanya adalah kekayaan bersama yang dapat digunakan setiap orang, yang harus dijaga untuk kepentingan masyarakat dan untuk generasi mendatang. Perlindungan lingkungan hidup dan sumberdaya alamnya dengan demikian mempunyai tujuan ganda, yaitu melayani kepentingan masyarakat secara keseluruhannya dan melayani kepentingankepentingan individu." Lihat Suparmoko, M, 1997, Ekonomi Sumberdaya Alam dan Lingkungan (Suatu Pendekatan Teoritis), BPFE, Yogyakarta, hlm. 56-57. 
keistimewaan yang terkandung di dalamnya. ${ }^{13}$ Ironisnya Sedulur Sikep komunitas lokal (indigenous people) yang hidup di sekitar dan bergantung dari keberadaan SDA dan $\mathrm{LH}$ di Pegunungan Kendeng itu justru terancam tercerabut dari akar budayanya, akibat 'permainan' ekonomi global [cq. rencana penambangan dan pendirian pabrik semen di Pati] yang dikendalikan industrialis-kapitalis. Lebih menyedihkan lagi, posisi komunitas lokal justru semakin termarjinalkan dalam proses tersebut. Bagan berikut mengenai faktualisasi nilai-nilai kearifan lokal masyarakat adat Sedulur Sikep di Pati.

Rencana pendirian Pabrik Semen PT $S G^{14}$ di Sukolilo mengundang sejumlah

13 Dalam wacana teoritik, keadaan seperti ini dikategorikan sebagai tacit culture. Dan pada umumnya pengetahuan lokal (indigenous knowledge) memang merupakan sesuatu yang bisa dinyatakan sebagai "...tacit knowledge and therefore difficult to codify, it is embedded in community practices, institutions, relationships and rituals". Pengetahuan itu tidak tertulis, tapi ia melekat dalam praktik-praktik, institusi, hubunganhubungan, dan ritus-ritus yang diselenggarakan oleh suatu komunitas. Pengetahuan, kebiasaan, dan aturan dalam masyarakat sebagai kearifan lokal masyarakat adat Sedulur Sikep menghadapi ancaman laten, diantaranya: (i) kurangnya penghayatan terhadap nilai-nilai kearifan lokal yang diturunkan pada generasi berikutnya; dan (ii) kurangnya perlindungan (proteksi) pemerintah, baik segi moril (political will), maupun materiil, (bahkan pemerintah secara langsung maupun tidak memberikan ijin pendirian pabrik semen yang berpotensi merusak tradisi ekologis Sedulur Sikep). Dengan demikian, dibutuhkan kehati-hatian dalam penerapan pranata sosial berbasis nilai kearifan lokal adat dalam pengelolaan SDA. Lihat Orlove, Benjamin. "Ecological Anthropology", Annual Review in Anthropology, Vol. 9, Redgrave Publishing Company, USA, 1980, hlm. 235-273.

14 Semen Gresik Group merupakan produsen semen terbesar di Indonesia. Produk semen yang diproduksi oleh PT. Semen Gresik adalah sebagai berikut: (i) Semen Portland Tipe I. Dikenal pula sebagai ordinary Portland Cement (OPC), merupakan semen hidrolis yang dipergunakan secara luas untuk konstruksi umum, seperti konstruksi bangunan yang tidak memerlukan persyaratan khusus, antara lain : bangunan, perumahan, gedung-gedung bertingkat, jembatan, landasan pacu dan jalan raya; (ii) Semen Portland Tipe II. Di kenal sebagai semen yang mempunyai ketahanan terhadap sulfat dan panas hidrasi sedang. Misalnya untuk bangunan di pinggir laut, tanah rawa, dermaga, saluran perdebatan sengit yang akhirnya membelah mayarakat ke dalam dua kutub yang saling bertentangan: pro dan kontra. Gambar berikut dapat memperjelas posisi komunitas Sedulur Sikep sebagai komunitas studi dalam peta konflik rencana kebijakan pendirian pabrik semen PT Semen Gresik (SG) di Sukolilo Pati ${ }^{15}$.

Banyak sekali tulisan kepustakaan hasil penelitian akademik mengenai keberadaan komunitas Sedulur Sikep yang cukup mewakili beragam perspektif yang ada, diantaranya: (i) Lance Castle dan Harry J. Benda ${ }^{16}$

irigasi, beton massa dan bendungan; (iii) Semen Portland Tipe III. Semua jenis ini merupakan semen yang dikembangkan untuk memenuhi kebutuhan bangunan yang memerlukan kekuatan tekan awal yang tinggi setelah proses pengecoran dilakukan dan memerlukan penyelesaian secepat mungkin. Misalnya digunakan untuk pembuatan jalan raya, bangunan tingkat tinggi dan bandar udara; (iv) Semen Portland Tipe V. Semen jenis ini dipakai untuk konstruksi bangunan-bangunan pada tanah/air yang mengandung sulfat tinggi dan sangat cocok untuk instalasi pengolahan limbang pabrik, konstruksi dalam air, jembatan, terowongan, pelabuhan dan pembangkit tenaga nuklir; (v) Special Blended Cement (SBC). Semen khusus yang diciptakan untuk pembangunan mega proyek jembatan Surabaya-Madura (Suramadu) dan cocok digunakan untuk bangunan di lingkungan air laut. Dikemas dalam bentuk curah; dan (vi) Portland Pozzolan Cement (PPC). Semen Hidrolis yang dibuat dengan menggiling terak, gypsum dan bahan pozzolan. Digunakan untuk bangunan umum dan bangunan yang memerlukan ketahanan sulfat dan panas hidrasi sedang. Misalnya, jembatan, jalan raya, perumahan, dermaga, beton massa, bendungan, bangunan irigasi dan fondasi pelat penuh. Melalui http://www.bumn.go.id/semenindonesia/, [09/09 /2014].

15 Diadaptasi dari Meida, Avid Nur, Purwoko dan Setyono,Budi. "Konflik Corporate vs. Society: Analisis terhadap Konflik dalam Kasus Pendirian Pabrik Semen di Kecamatan Sukolilo Kabupaten Pati". Dalam Journal of Politic and Government Studies, Vol. 2, No. 2, 2013, hlm. 123-132.

16 Castle dan Benda sedikit banyak menyebut semangat kembali pada ajaran Jawa kuno sebagai pembangkit gerakan Saminisme. Selain itu juga dipengaruhi persoalan kemiskinan yang dialami petani-petani Jawa, sebagaimana istilah para sejarahwan seperti 'seorang yang terendam air di sungai sampai di bibirnya sehingga jika sedikit saja diterpa angin ia akan tenggelam'. Kemiskinan petani tegalan dan efek dualisme ekonomi kolonial serta perluasan hutan negara kolonial bagi keduanya merupakan konteks khusus yang mendorong 


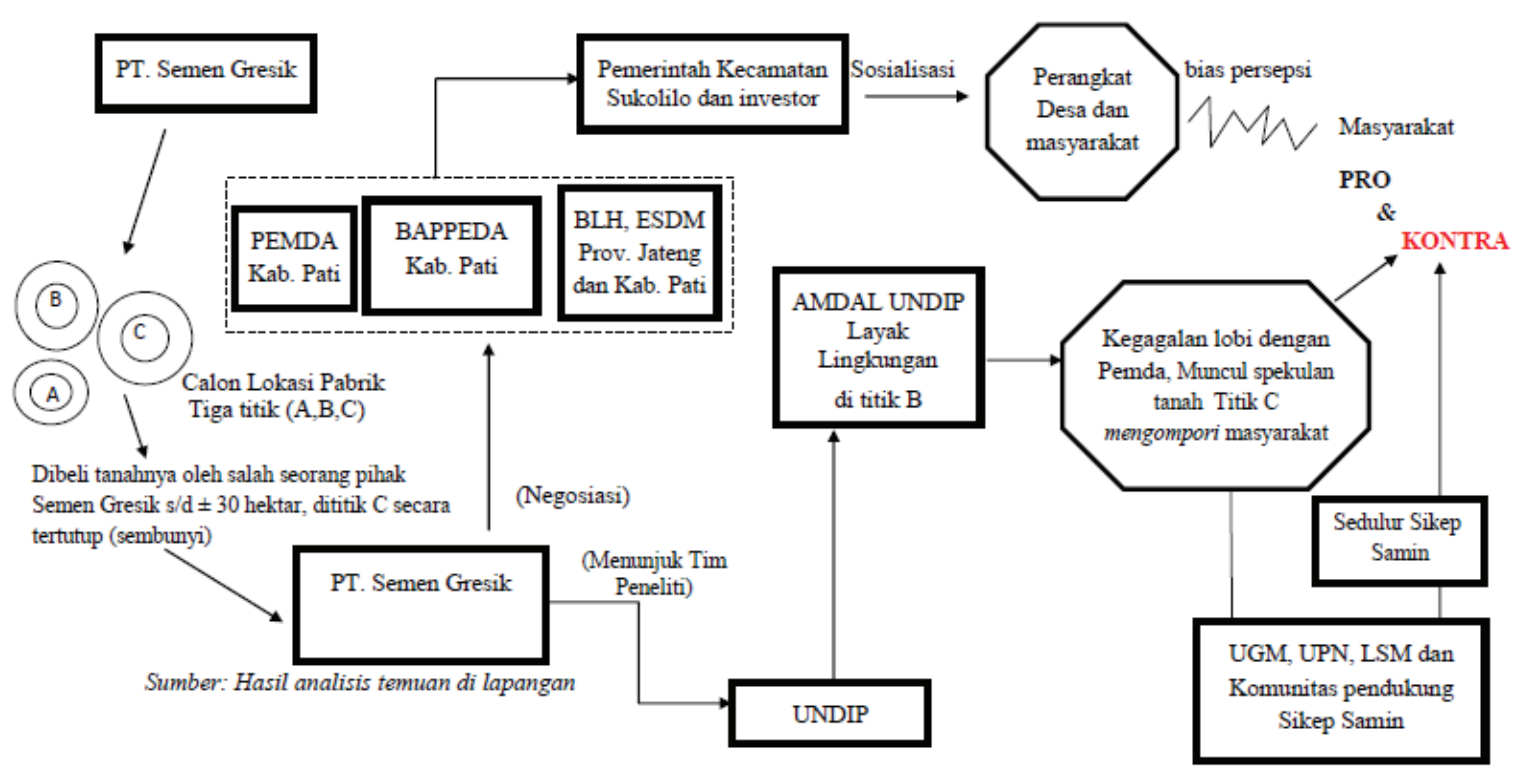

(1969), "The Samin Movement"; (ii) Victor T. King ${ }^{17}$ (1973), "Some Observations on The

kelahiran "Gerakan Saminisme". Lihat Castle, Lance dan Benda, Harry J. "The Samin Movement", $B K I$, deel 135, 1e aflevering, Matinus Nijhoff, 'sGravenhage, 1969, hlm. 41. Lihat juga Castle, Lance dan Benda, Harry J. "The Samin Movement", Reprint Series, Vol. 125, No. 37. New Haven, Yale University, Southeast Asia Studies, Conn., 1969, hlm. 207-240.

17 King memusatkan perhatiannya pada persoalan teoritis yang dipakai untuk menyangkal pendapat Lance Castle dan Harry J. Benda yang menggunakan pendekatan mono-kausal terkait "Gerakan Saminisme". Dalil utama yang dikemukakan King adalah, bahwa determinisme ekonomi yang dianut Castle dan Benda telah gagal menjelaskan mengapa banyak petani miskin, di sekitar daerah pantura (Pantai Utara) Jawa Tengah dan sebagian kecil di perbatasan Jawa Timur, memilih tidak bergabung dengan Gerakan Saminisme. King sendiri berargumen, bahwa bila dilihat dari ciri gerakannya yang pasif dan rasional, Saminisme dinilai merupakan gerakan petani kelas menengah, di mana faktor materi dan kemiskinan bukanlah menjadi kausalitas utama Gerakan Samin, melainkan faktor sosial "keluhan" ekonomi dalam aspek kehidupan agraria melalui teori keresahan/ kerusuhan pedesaan "rural unrest", khususnya soal diferensiasi struktur sosial masyarakat Jawa pedesaan pada saat itu. Terdapat semacam pergantian poros kekuasaan/pengaruh sosial politik. Para pemilik tanah yang sebelumnya mendapati posisi penting dalam kebijakan desa, pada gilirannya status sosial politik tersebut berkurang seiring peraturan pemerintah tahun 1906 yang menempatkan kepala desa sebagai satu-satunya pejabat yang mengambil keputusan. Tokoh yang tidak masuk dalam pejabat birokrasi desa merasa ada "perongrongan status" atas diri mereka. Lihat
Samin Movement of The North-Central Java"; (iii) Pieter E. Korver ${ }^{18}$ (1976), "The Samin Movement And Millenarism"; (iv) Suripan Sadi Hutomo ${ }^{19}$ (1985), "Samin Surosentiko dan Ajaran-Ajarannya”; (v) Nancy Lee Peluso 20 (1992), "Rich Forest Poor People: Resource Control and Resitance in Java "; (vi) Amrih

King, Victor T. "Some Observations on The Samin Movement of The North-Central Java", BKI, deel $129,4 \mathrm{e}$ aflevering, Matinus Nijhoff, 's-Gra-venhage, 1973, hlm. 461-463.

18 Korver membantah pendapat King yang menurutnya tidak berbeda dengan hipotesis mono-kausalitasnya Castle dan Benda. Menurut Korver, gerakan Samin merupakan gerakan mileniarisme. Untuk mencari kausalitasnya, maka perlu untuk mengkomparasikan dengan gerakan-gerakan mileniarisme yang lain. Komparasi tersebut untuk menghindari kemandegan analisis kausalitas gerakan Samin yang acapkali berhenti pada kesimpulan kausalitas tunggal. Korver meyakini bahwa kausalitas gerakan Samin sangat beragam. Gerakan milinearisme selalu disebabkan oleh kombinasi faktor-faktor yang berbeda-beda serta keterkaitan diantaranya. Lihat Korver, Pieter E. "The Samin Movement and Millenarism", BKI, deel 132, 2e+3e aflevering, Matinus Nijhoff, 'sGravenhage, 1976, hlm. 249-266.

19 Hutomo, Suripan Sadi. "Samin Surontiko dan Ajaran-Ajarannya", Basis, No.1-2, JanuariPebruari, 1985, hlm. 4

20 Peluso menyebutkan bahwa kebijakan kehutanan pemerintah kolonial Belanda menjadi latarbelakang munculnya Gerakan Saminisme. Lihat Peluso, Nancy Lee. Rich Forest Poor People: Resource Control and Resistance in Java, University of California Press, New York, 1992, hlm. 85. 
Widodo 21 (1997), "Samin In The New Order: The Politic of Encounter and Isolation"; dan (vii) Emmanuel Subangun 22 (1997), "Tidak ada Mesias dalam Pandangan Hidup Jawa". Tulisan-tulisan tentang Sedulur Sikep di atas hanya merupakan sebagian dari sekian banyak tulisan yang membahas tentang komunitas ini sesuai masanya. Penelitian disertasi ini bermaksud menyajikan datadata terkini dan kontemporer mengenai komunitas Sedulur Sikep

Masyarakat atau Komunitas Sedulur Sikep ${ }^{23}$ atau yang dahulu akrab dengan sebutan "Suku Samin" merupakan pengikut Ki Samin Surosentiko ${ }^{24}$ yang berada di

21 Amrih Widodo dengan gamblang menjelaskan relasi antara bahasa komunitas Samin dengan Agama Adam yang mereka yakini. Lihat Widodo, Amrih. "Samin In The New Order: The Politic of Encounter and Isolation". Dalam Jim Schiller dan Barbara Martin Schiller (Penyunting), Imagining Indonesia, Cultural Politics and Political Culture, Ohio University Press, Ohio, 1997, hlm. 261-287.

22 Subangun berpendapat bahwa persaingan dan perongrongan status (status deprivation) kelompok petani kaya pemilik tanah, seperti Samin Surosentiko inilah yang merupakan casus belli, dan masalah pajak serta masalah perampasan tanah rakyat yang kemudian menjadi dasar ikatan rakyat petani yang lebih miskin. "Gerakan itu tidak muncul dari kepahitan pengalaman bersama, tapi adalah dimulai dari kekecewaan elit dalam masyarakat petani, dan rakyat banyak kemudian menjadi pengikut gerakan". Lihat Subangun, Emmanuel, "Tidak ada Mesias dalam Pandangan Hidup Jawa”. Dalam Prisma, No. 1, Januari 1997, hlm. 26-37.

23 Komunitas Sedulur Sikep adalah istilah untuk menunjuk suatu entitas organik yang terdiri atas sekumpulan individu dengan kesamaan identitas tertentu (unifying traits), seperti kesamaan geografis tempat tinggal, ideologi atau agama, kepentingan/ kebutuhan/aspirasi, minat dan bakat, serta profesi yang ada di sekitar Pegunungan Kendeng di wilayah utara yang memanjang mulai dari Provinsi Jawa Tengah hingga Provinsi Jawa Timur. Komunitas studi penelitian ini adalah Sedulur Sikep di Kecamatan Sukolilo, Kabupaten Pati Provinsi Jawa Tengah.

24 Samin Surosentiko lahir di Plosokediren, Randublatung, Blora pada tahun 1859, anak dari seorang bangsawan Bojonegoro (ada yang menyebut dari Ponorogo) bernama R. Surowijoyo (atau disebut Samin Sepuh). Agar sosok tersebut lebih merakyat nama R. Kohar diganti menjadi nama Samin. Kemudian dilengkapi menjadi Samin Surosentiko dan bergelar Panembahan Suryongalam. Samin memiliki hubungan sejarah dengan Pura Mangkunegaran di Surakarta,
Sukolilo, Pati dan sekitarnya nampaknya berhasil membentuk semacam enclave (kantong) budaya sehingga mereka terkenal dengan sebutan "Sedulur Sikep Enam Desa". "Komunitas Sedulur Sikep Enam Desa", merupakan istilah untuk menyebut masyarakat Sedulur Sikep yang ada di Dusun Bombong-Bacem (Desa Baturejo), Galiran (Desa Baleadi), Ngawen (Desa Sukolilo), Curug (Desa Kedungmulyo), Kaliyoso (Desa Karangrowo), dan Kuthuk ${ }^{25}$ (dua desa terakhir ada di wilayah Kecamatan Undakan, Kudus) ${ }^{26}$ Saminisme ${ }^{27}$, secara antropologis

tetapi tidak mau membawa-bawa nama Pura Mangkunegaran tersebut, agar tidak mengotori kebaikan namanya di mata masyarakat, terutama di depan penjajah Belanda. Lihat Mulder, Niels. "Saminisme and Budhisme: A Note on Field Visit to a Samin Community", Asian Quarterly, No. 3, 1974, hlm. 72-84. Lihat juga Hutomo, Suripan Sadi. "Samin Surontiko dan...., Op.Cit., hIm. 1-2.

25 Desa ini disebut oleh Pieter Korver, "The movement never quite disappeared. So there were references to Saminists in the former regency of Blora still as late as the late 1960's (the 1967). And in 1973 a Dutch researcher paid a visit to a community of Saminists in the village of Kutuk in the Kabupatèn of Kudus, in the former residency of Semarang. Of a total population of 5.000 of this desa, allegedly 2.000 persons were Saminists (Mulder). Prior to 1920 the total number of followers of the movement never at any one time exceeded 3.000 heads of households,". Lihat, Korver, Pieter E. "The Samin Movement and Millenarism", BKI, deel 132, 2e+3e aflevering, Martinus Nijhoff, 'sGravenhage, 1976, hlm. 249.

26 Daerah Bombong-Bacem, Baturejo merupakan pusat wilayah dari masyarakat Sedulur Sikep di Sukolilo. Hal ini karena beberapa leluhur Sedulur Sikep di Sukolilo berasal dari wilayah ini. Selain itu, sampai sekarang musyawarah (Rembugan) anggota komunitas Sedulur Sikep di Sukolilo selalu diadakan di rumah tokoh-tokoh Sedulur Sikep yang ada di Bombong-Bacem. Hasil wawancara dengan Tarjo dan Parini, warga adat Samin BombongBacem, Baturejo Pati [10/12/2014].

27 Penyebab pertama dan utama atas gerakan Samin adalah konflik antara Kaum Samin dengan otoritas di atasnya (struktural pemerintahan kolonial) yang merupakan perwujudan resistensi dari tekanan ekonomi yang dialami, terutama terkait dengan kenaikan pajak, tanah, air, dan akses kayu jati (intervensi pemerintah kolonial dalam bidang kehutanan melalui peraturan kehutanan). Beberapa fakta tentang semakin beratnya beban ekonomi masyarakat Samin disebutkan misalnya ketika pemerintah Hindia Belanda mendatangkan kerbau dari Bengal atau Bangladesh, masyarakat Samin 
merupakan fenomena gerakan petani yang tertua di Asia Tenggara, yang oleh banyak sejarawan disebut proto-nasionalisme. ${ }^{28} \mathrm{~J}$.E.

diharuskan menyerahkan uang 5 sampai 10 gulden. Dan sering kali masyarakat Samin masih diminta untuk bekerja bagi pemeliharan kerbau tersebut, tanpa dibayar. Hal ini mengurangi waktu bekerja masyarakat Samin dalam kehidupan bertani seharihari di sawahnya masing-masing. Selain itu, di beberapa desa dilakukan pengurangan luasan terhadap tanah-tanah komunal yang dikerjakan bergilir oleh para petani. Pengurangan tersebut tidak termasuk tanah bengkok milik pejabat desa. Sementara dalam sektor kehutanan, pembatasan akses masyarakat terhadap hutan dimulai sejak Daendels berkuasa di Jawa. Sejak saat itu, hutan menjadi milik Negara Kolonial. Pengelolaan hutan dilakukan oleh negara melalui sebuah lembaga yang bernama Boschwezen. Masyarakat sudah mulai dibatasi aksesnya terhadap hutan dengan harus mengurus ijin ketika akan menebang pohon. Kemudian pada tahap selanjutnya, pembatasan tersebut semakin jelas ketika muncul peraturan kehutanan pertama tahun 1865 serta disusul oleh Undang-Undang Agraria tahun 1870 yang memisahkan secara tegas, di mana lahan masyarakat berakhir dan kawasan hutan di mulai. Peraturan-peraturan kehutanan tersebut telah membatasi hubungan antara masyarakat dengan hutannya. Samin dan pengikutnya tidak terkecuali terkena dampak tersebut. Mengingat Samin dan pengikutnya menyandarkan hidup pada pertanian dan kehidupan berhutan. Wilayah yang paling dipengaruhi oleh sistem baru ini, pertama-tama adalah wilayah Blora dan Grobogan. Sebagaimana yang diungkapkan oleh Benda dan Castles: "Tidak ada wilayah yang lebih dipengaruhi oleh inovasi kehutanan ini melainkan wilayah Blora dan Grobogan. Hingga pada tahun 1918, hampir semua hutan di kedua wilayah ini telah menjadi Houtvesterijen (Houtvesterij). Inovasi pengelolaan hutan tersebut menjadi pusat sumber pendapatan bagi pemerintah kolonial Belanda". Lihat Castle, Lance dan Benda, Harry J. "The Samin Movement", Reprint Series, Vol. 125, No. 37. New Haven, Yale University, Southeast Asia Studies, Conn., 1969, hIm. 219-222.

28 Proto-nasionalisme adalah suatu bentuk nasionalisme awal. Sebuah rintisan kesadaran kebangsaan. Dalam Kamus Besar Bahasa Indonesia, proto diartikan yang paling dasar atau bawah; yang pertama; yang terdahulu. Sementara nasionalisme diartikan sebagai paham (ajaran) untuk mencintai bangsa dan negara sendiri, bersifat kenasionalan; kesadaran keanggotaan dalam suatu bangsa yang secara potensial atau aktual bersama-sama mencapai, mempertahankan dan mengabadikan identitas, integritas, kemakmuran, dan kekuatan bangsa itu; semangat kebangsaan. Widodo, Amrih. "Untuk Hidup Tradisi Harus Mati". Basis, September-Oktober 2000, hlm. 16.
Jasper $^{29}$ dan Tjipto Mangoenkoesoemo, ${ }^{30}$ meski berseberangan garis politik, keduanya sama-sama menilai bahwa Saminisme tak lebih dari cerminan abnormalitas dan anarkisme petani belaka yang muncul sebagai akibat imbas kebijakan-kebijakan pemerintah kolonial yang eksploitatif dan memberatkan. ${ }^{31}$ Komunitas Sedulur Sikep dalam sejarah hubungannya dengan kekuasaan negara dipenuhi dengan nuansa "kekerasan kultural" ${ }^{32}$, baik aspek budaya, ranah simbolik eksistensi agama dan ideologi, ekonomi, bahasa dan seni, maupun aspek lainnya yang dapat digunakan untuk menjustifikasi, atau melegitimasi kekerasan langsung. Sedulur Sikep dalam menyikapi perbedaan atau konflik menolak anarkisme dan lebih memilih sikap anti kekerasan. Perjuangan dan sikap kritis Sedulur Sikep dilandasi nilai dan moralitas perdamaian yakni ketaatan terhadap aturan dan prinsip hidup yang dipegang, diyakini dan diimplementasikan bersama untuk mengembangkan hal-hal baik dalam jalinan keterhubungan atau komunikasi dan interaksi dalam kehidupan berbangsa dan bernegara. Keberadaan nilainilai Sedulur Sikep melekatkan konstruksi identitas keyakinannya pada pertanian. Bagi

29 Jasper, J.E. Verslag Betreffende het Onderzoek in Zake de Saminbeweging Ingesteld Inge-volge het Gouvernement Besluit van 1 Juni 1917, No. 20, (Batavia, 1918). Lihat dalam Castle, Lance dan Benda, Harry J. "The Samin..., Op.Cit., hlm. 208.

30 Mangoenkoesoemo, Tjipto. Het Saminisme: Rapport Uitgebracht aan de Ver-eeniging Insulinde, (Semarang, 1918). Lihat dalam Castle, Lance dan Benda, Harry J. "The Samin..., Op.Cit., hlm. 208.

31 J.E. Jasper adalah asisten residen Tuban yang pada tahun 1917 diminta melakukan penelitian tentang gerakan Saminisme oleh pemerintah kolonial Belanda karena kekhawatiran akan meningkatnya gerakan petani pada kurun waktu tersebut. Sementara Tjipto Mangoenkusumo adalah salah seorang garda depan perjuangan kemerdekaan Indonesia yang jelas-jelas anti-kolonial. Lihat Onghokham, Saminisme: Tindjauan Sosial Ekonomi dan Kebudajaan Pada Gerakan Tani Dari Awal Abad Ke-XX, Djambatan, Djakarta, 1964, hlm. 119. Lihat juga Amrih Widodo, "Untuk Hidup Tradisi Harus Mati”. Basis, September-Oktober, 2000, hlm. 15-17.

32 Galtung, Johan, 2003, Studi Perdamaian, Perdamaian dan Konflik, Pembangunan dan Peradaban, Terjemahan Asnawi dan Safruddin. Pustaka Eureka, Surabaya, hlm. 429. 
petani [khususnya warga Sedulur Sikep], Pegunungan Kendeng adalah bagian dari kehidupan mereka yang patut diuri-uri (dipelihara dengan baik dan benar). ${ }^{33}$ Selain itu, Sedulur Sikep beranggapan bahwa pekerjaan tani mencerminkan kejujuran, yang akan melahirkan keadilan untuk sampai kepada kebenaran dan kepatutan.

2. Legal Policy Daerah Berbasis Nilai-Nilai Local Genius Sedulur Sikep dalam Pengelolaan SDA dan Pelestarian LH Kebijakan hukum berbasis kearifan lokal di bidang pengelolaan SDA dan pelestarian LH muncul dalam sejumlah fakta yang secara diametral mengandung kontradiksi; (i) terjadinya tumpang tindih peraturan yang satu dengan peraturan yang lain, bahkan juga saling melengkapi kelemahan masing-masing sehingga pelanggaran terhadap peraturan yang satu dibenarkan oleh peraturan yang lainnya; (ii) involusi regulasi yang ditandai oleh dilema harmonisasi antara nilai konstitutif yang merupakan struktur tekstual sistem hukum pengelolaan SDA dan pelestarian LH [yang berbasis ideologi kapitalis] dan nilai-nilai kearifan lokal sebagai struktur kontekstual yang merupakan dimensi fungsionalnya, yakni pemberdayaan ekonomi berbasis ideologi sosialis-kerakyatan; ${ }^{34}$ dan

33 Itulah sebabnya, di Pegunungan Kendeng terdapat pula beberapa situs yang dikenang sebagai pusat kehidupan dan pemelihara kehidupan, misalnya situs Watu Payung. Situs ini kerapkali dikunjungi oleh penjelajah spiritual dan orang-orang yang meyakini secara simbolik "kemuliaan" situs ini. Secara ilmiah, beberapa pusat kajian juga banyak menyebutkan data mengenai kekayaan yang terkandung di kawasan Kendeng. Pegunungan Kendeng memiliki bentukan bukit dan lembah yang khas akibat prosesproses pelarutan, terdapat goa-goa, aliran sungai bawah tanah, dan mata air. Perusakan kawasan batu gamping ini akan mempengaruhi ekosistem untuk daerah yang jauh lebih luas daripada yang diperkiraan. Ujung-ujungnya, korban terakhirnya adalah umat manusia karena alam di sana memiliki mekanisme pertahanan yang sempurna. Jika tekanan terhadap dirinya makin berat, maka bisa jadi dia akan menyeimbangkan dirinya dengan cara membuat bencana alam agar dapat mengurangi populasi manusia. Hasil wawancara dengan Gunretno, tokoh muda adat Samin Pati [10/12/2014].

34 Dalam sosiologi hukum Weberian, dua nilai dimaksud disebut dengan istilah sumbu formal substantif dan sumbu irrasional-rasional. Sumbu formal- (iii) tak terhindarkannya pengaturan yang inconsistency internally akibat keberpihakan pada ideologi yang semata-mata mengusung liberalisasi pengelolaan SDA dan pelestarian $\mathrm{LH}^{35}$

Interrelasi dialektis menuju kebijakan hukum daerah berbasis nilai-kearifan lokal yang responsif dan progresif menemui kontradiksi, meliputi: (i) kontradiksi antara fakta dan nilai dalam legal policy dan local genius, karena nilai-nilai sosial berkelindan dengan fakta-fakta yang melembaga dalam pengaturan hukum adat maupun hukum negara; (ii) kontradiksi dalam hubungan kausalitas yang tidak satu arah dalam proses dialektika hukum adat dan hukum negara; dan (iii) kontradiksi antara karakter pengaturan substantif menyangkut penyusunan hukum, dalam hal ini menyangkut isi, prosedur dan formulasinya; sedangkan sumbu irasional-rasional merujuk pada ukuran-ukuran diluarnya. Rahardjo, Satjipto, 2000, IImu Hukum, Citra Aditya Bhakti, Bandung, hlm. 261-262.

35 Laporan Komisi Brundtland (1987) merupakan pengertian hukum yang luas dan dianut secara luas yang memberikan pengertian 'sustainable development' sebagai: '...development that meets the needs off the present without compromising the ability of future generation to meet their own needs'. Ada dua konsep penting dalam rumusan tersebut: (i) konsep kebutuhan (needs) terutama kebutuhan dasar generasi saat ini; dan (ii) ide keterbatasan yang didasarkan pada pertimbangan kemajuan teknologi dan organisasi sosial untuk menetapkan daya dukung lingkungan yang mampu menopang kehidupan generasi sekarang dan generasi masa depan. Selanjutnya, Laporan Brundtland (1987), mengidentifikasikan beberapa masalah kritis yang perlu dijadikan dasar kebijakan hukum lingkungan bagi konsep pembangunan berkelanjutan, yaitu: (i) mendorong pertumbuhan dan meningkatkan kualitas (reviving growth and changing its quality); (ii) mendapat kebutuhan pokok mengenai pekerjaan, makanan energi, air, dan sanitasi (meeting essestial needs for jobs, food, energy, water, and sanitation); (iii) menjamin tingkat pertumbuhan penduduk yang mendukung keberlanjutan (ensuring asustainable level of population); (iv) melakukan konservasi dan kemampuan sumberdaya (conserving and enhancing the resource base); (v) orientasi teknologi dan mengelola resiko (reorienting technology and managing risks) dan; (vi) memadukan pertimbangan lingkungan ekonomi dalam proses pengambilan keputusan (merging environment and economics in decision-making). Lembaga Studi dan Advokasi Masyarakat (ELSAM), "Hak Asasi Manusia Tanpa Dukungan Politik, Catatan HAM Awal Tahun 2008", Melalui http://www.elsam.or.id; [12/08/2014]. 
hukum adat dan hukum negara di masa lalu, masa sekarang dan masa akan datang. Hal ini penting karena nilai-nilai kearifan lokal yang menandai pengaturan hukum adat dan norma hukum positif yang menandai hukum negara dipahami sebagai sebuah konstruksi sosial yang dialektis.

Tinjauan terhadap pergeseran pengaturan di bidang pengelolaan SDA dan pelestarian LH berbasis kearifan lokal (Sedulur Sikep dengan nilai kejujuran, keadilan dan kebenaran/kepatutan), ke pengaturan yang melegitimasi ekonomi pasar (industrialisasi kapitalistik melalui pembangunan pabrik semen di Sukolilo Pati) menjadi inheren. Semua pergeseran dipahami tidak sebagai sesuatu yang berlangsung secara alami, tetapi sarat kontradiksi, negasi dan bahkan mediasi untuk membenarkan atau diterimanya ide tertentu dari ekonomi pasar dalam pengaturan hukum formal yang berkelindan dengan nilai kearifan lokal [hukum adat].

Interrelasi dialektis nilai-nilai kearifan lokal dan kebijakan hukum daerah di bidang pengelolaan SDA dan pelestarian LH tidak selalu paralel dengan cita hukum Pancasila dan kehendak UUD NRI 1945 untuk beberapa alasan: (i) adanya fakta bahwa pada aras teoretis pengelolaan SDA dan pelestarian LH berwajah ganda atau ambivalen [antara ide (nilai) pelestarian SDA-LH dengan fakta pada aras implementasinya yang menciptakan kondisi ketergantungan ekonomi; dan antara kehendak (nilai) pemberdayaan masyarakat dengan model tata kelola SDA-LH berbasis eksploitatif sebagai hidden agenda]; (ii) legal policy pengelolaan SDA dan pelestarian $\mathrm{LH}$ ini lebih ditandai kehendak untuk berpihak pada ekonomi pasar semata; dan (iii) dialektika legal policy pengelolaan SDA dan pelestarian LH tidak hanya kontradiksi dan atau negasi sematamata terhadap local genius, karena bersamaan dengan itu terdapat pula pembenaran untuk sebagian kecil konsep ataupun ide perihal ekonomi kerakyatan yang menandai legislasi/ regulasi daerah untuk periode tertentu. Secara skematis interrelasi dialektis tersebut dapat digambarkan dalam bagan berikut.

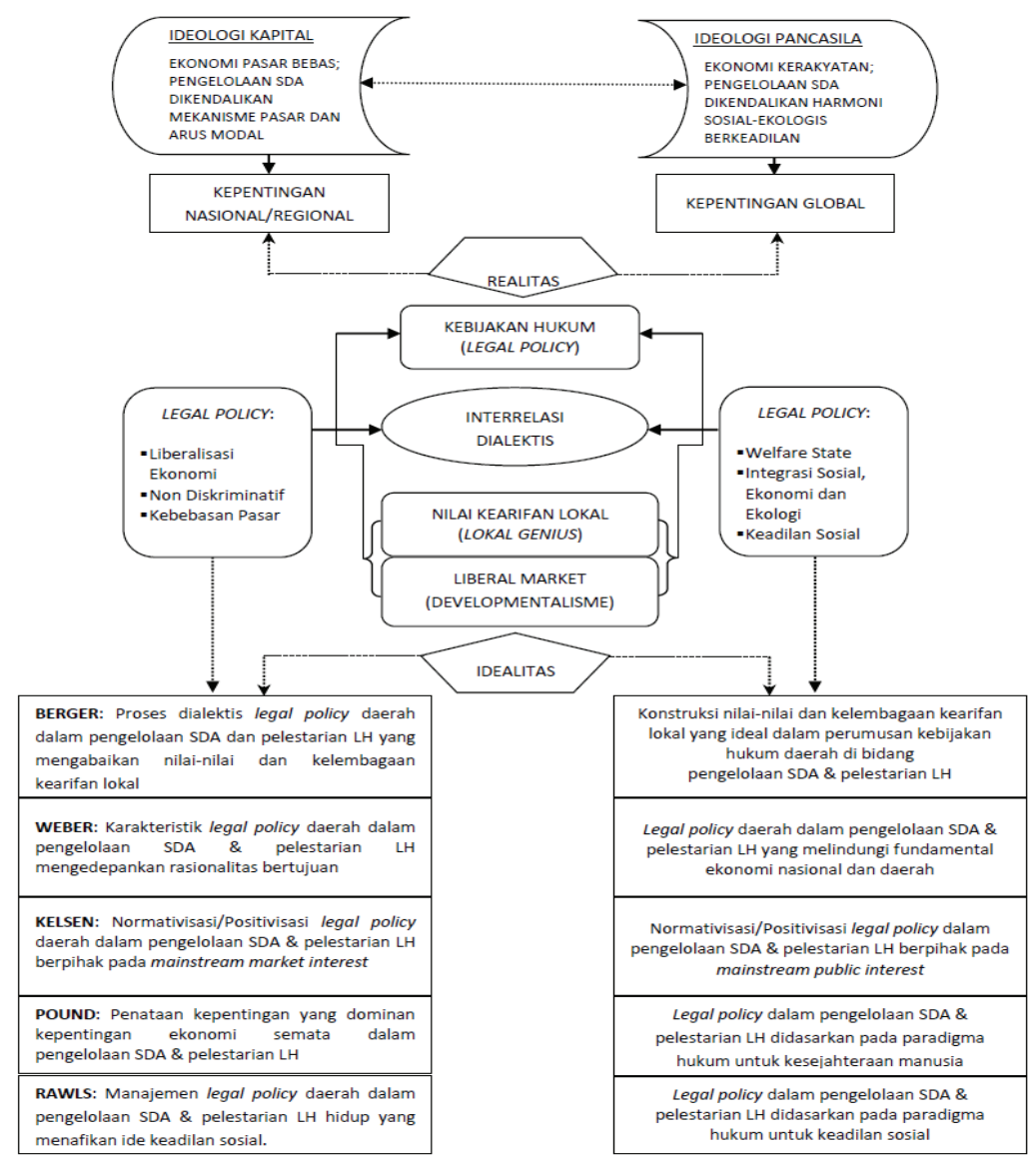


Pada skema di atas, proses interrelasi dialektis nilai-nilai kearifan lokal dan kebijakan hukum daerah dalam pengelolaan SDA maupun pelestarian LH diasumsikan harus selalu bersesuaian dengan cita hukum Pancasila. Idealnya, proses interrelasi dialektis yang menandai dinamisasi ide pengelolaan SDA (in casu pendirian pabrik semen) tidak menyebabkan disintegrasi sosial, ekonomi maupun ekologi (pelestarian $\mathrm{LH}$ ), tetapi sebaliknya berwujud proteksi maksimal terhadap integrasi sosial dan bahkan kedaulatan ekonomi bangsa maupun keberlanjutan ekologi. Selain itu proses interrelasi dialektis legal policy daerah sejatinya tidak boleh bertentangan dengan gagasan keadilan sosial, prinsip equality before the law dan tujuan mewujudkan welfare rechtsstaat yang diamanatkan oleh UUD NRI 1945, sebagai nilai luhur yang harus diemban semua pranata hukum tak terkecuali kebijakan hukum daerah.

Di arena legal policy formulation, nilainilai kearifan lokal yang terkristalisasi dalam Pancasila maupun kaidah mendasar yang diatribusikan oleh UUD NRI 1945 harus selalu menjadi panduan dalam law making procces, law administration process, maupun law enforcement process. Fakta existing ketidak-berdayaan daerah terhadap tekanantekanan lingkungan strategis (global maupun nasional), menjadikan legal policy formulation membentuk karakter hukum daerah yang secara interrelatif dialektis arahnya ditentukan oleh beberapa variabel bebas, yakni: (i) model kapitalisasi dan transnasionalisasi ${ }^{36}$

36 Proses transnasionalisasi hukum, menurut Boaventura De Sausa Santos dilakukan melalui beberapa kecenderungan. Santos mengkonstatasi: "...i tried to reconstruc these multiple tensions analytically by identifying the four major forms of transnationalization in which they are played out and the defined according to the spesific dominan organizing principles underlying them: globalized localism; localized globalism; cosmopolitanism; common heritage of human kind. Semua kecenderungan ini menurut Santos, merupakan pilihan menuju sebuah ecumene di berbagai bidang kehidupan global. Khusus di bidang hukum, Santos memahaminya sebagai cara atau pilihan divestasi dari legal diaspora ke legal ecumene. Santos, Boaventura De Sousa, 1995, Toward A hukum pengelolaan SDA-LH; (ii) pendekatan (approach) yang dipilih dalam law making procces; dan (iii) problem ketiadaan arah politik hukum nasional dalam pengelolaan SDA dan pelestarian $\mathrm{LH}$.

3. Model Fungsionalisasi Nilai-Nilai Kearifan Lokal (Local Genius) dalam Kebijakan Hukum (Legal Policy) di Bidang Pengelolaan SDA dan Pelestarian LH Sesuai dengan Cita Hukum Pancasila

Pemanfaatan SDA-LH yang terlalu bebas akan cenderung over eksploitatif, dan mengakibatkan tragedy of the common. Karena itu, precautionary principles pada intinya menempatkan isu-isu kepemilikan bersama (common property) terkait erat dengan cara-cara bagaimana sumberdaya yang dimiliki dan dapat diakses bersama dalam suatu komunitas dapat dilindungi dari kerusakan. Alternatif solusi yang dapat dilakukan adalah berupa: (i) intervensi kebijakan hukum; dan (ii) penguatan control dan coercion dari pemerintah. Namun demikian perlu dibedakan dengan tegas antara sumberdaya milik bersama yang dikategorikan open-acces resources dan communally owned resources. ${ }^{37}$

New Common Sense: Law, Science and Politics In Paradigmatic Transition, Routledge, New York, hlm. 231-239.

37 Open-acces resources adalah sumberdaya yang dapat diakses semua orang tanpa terkecuali dan tanpa batasan, yang pada dirinya belum dikenalkan suatu institusi pengelolaan tertentu oleh suatu komunitas atau negara. Sedangkan communally owned resources adalah sumberdaya yang dimiliki oleh suatu komunitas atau kelompok sosial tertentu, dan cara mengaksesnya telah diatur suatu institusi pengelolaan yang dibentuk oleh komunitas atau kelompok sosial tersebut. Contoh tradisi Sasi di Maluku maupun Eha di Talaud yang melarang masyarakat mengambil hasil sumberdaya tertentu untuk menjaga mutu dan pelestarian lingkungan hidup; Tradisi Huta Kera di Sangeh Bali yang melarang merusak hutan wisata; tradisi Ongko di Sulawesi Selatan yang mengakui kepemilikan seseorang atau kelompok masyarakat terhadap bagian hutan, sungai, rawa atau danau dan perairan pantai untuk dikelola dan dimanfaatkan; maupun tradisi Wanatani Repong Damar (damar agroforest) yang menegedepankan kesinambungan pengelolaan hutan secara lestari di Pesisir Krui, Lampung Barat. Lihat dalam Kisya, Eliza. Sasi Aman Haru Ukui: Tradisi Kelola Sumberdaya Alam Lestari di Ukui, Yayasan Sejati, Jakarta, 1993; Atmajda, 
Kebijakan hukum daerah ternyata belum mampu menghasilkan produk hukum yang terbuka dan tidak state oriented sehingga diperlukan model fungsionalisasi nilai-nilai kearifan lokal dalam kebijakan hukum daerah di bidang pengelolaan SDA \& pelestarian LH. Teori The Integratif Law-Society Framework merupakan temuan peneliti sebagai model fungsionalisasi Local Genius dalam Legal Policy daerah di bidang pengelolaan SDA dan peletarian LH sesuai cita hukum Pancasila.

The Integratif Law-Society Framework adalah konsep kebijakan hukum reformatif yang memiliki dimensi akomodatif-deliberatif dan integratif-restoratif. Hukum reformatif adalah legal futuristic, yang mampu memperhitungkan kepentingan bangsa dan negara untuk kurun waktu yang panjang, jauh ke depan, dan tidak sekedar untuk jangka pendek secara pragmatis. Kebijakan hukum akomodatif adalah konsep perumusan hukum yang mengakomodasi nilai-nilai kearifan lokal, dilandasi dengan fondasi bangunan politik negara berdasarkan Pancasila dan UUD NRI Tahun 1945. Adapun kebijakan hukum deliberatif adalah suatu proses perumusan legal policy yang legitimitasinya didapat melalui diskursivitas secara komprehensif via dua rel, yaitu memperbaiki sistem demokratis dan memperkuat etos demokratis [regierung der regierten (pemerintahan oleh yang diperintah)]. Legitimasi hukum bukan pada perolehan mayoritas, tetapi cara meraihnya fair dan adil sebagai alasan kuat untuk dipatuhi oleh warga negara. Adapun kebijakan hukum integratif adalah perekayasaan birokrasi dan masyarakat yang dilandaskan pada sistem norma, sistem perilaku, dan sistem

Nengah Bawa. "Pengelolaan Hutan Wisata Kera Sangeh oleh Desa Adat Sangeh". Dalam Ekonesia: a Journal of Indonesia Human Ecology, UI, Jakarta, Vol. 1, No. 1, 1993: hlm. 1-22; Lampe, Munsi. Sistem Penguasaan Wilayah Perikanan dan Pemanfaatan Sumberdaya Hayati Laut Oleh Masyarakat Nelayan Bugis, Makasar Sulawesi Selatan, Depdikbud RI, Jakarta, 1986; Lubis, Zulkifli. Repong Damar: Kajian tentang Pengambilan Keputusan dalam Pengelolaan Lahan Hutan di Pesisir Krui, Lampung Barat, CIFOR, Jakarta, 1997. Lihat juga Lubis, Zulkifli. Menyelaraskan Pola dan Ruang Pengelolaan Sumberdaya Milik Bersama, USU Press, Medan, 1999. nilai (system of values) yang bersumber pada Pancasila sebagai ideologi bangsa Indonesia. Sedangkan kebijakan hukum restoratif adalah fungsi hukum sebagai pemulihan sosial (social recuperation), yang mengutamakan perbaikan, rekonsiliasi dan perlindungan kembali secara dialogis dengan menempatkan keadilan dan kemanusiaan sebagai basis pengambilan keputusan, sehingga manusia menjadi pokok sentral dalam perumusan kebijakan hukum.

Kebijakan hukum yang demokratis setidaknya mempunyai karakter dan alur pikir bahwa: (i) hukum nasional/daerah dibuat sesuai dengan cita-cita bangsa, yakni masyarakat adil dan makmur berdasar falsafah negara; (ii) hukum nasional/daerah dirancang untuk mencapai tahap tertentu dari tujuan negara sebagaimana tertuang di dalam Pembukaan UUD 1945; dan (iii) hukum nasional/daerah harus menjamin integrasi bangsa dan negara baik teritori maupun ideologi, mengintegrasikan prinsip demokrasi dan nomokrasi, artinya pembangunan hukum harus mengundang partisipasi dan menyerap aspirasi masyarakat melalui prosedur dan mekanisme yang fair, transparan dan akuntabel; dan berorientasi pada pembangunan keadilan sosial; dan menjamin hidupnya toleransi beragama yang berkeadaban. Guna mewujudkan hal tersebut, maka kebijakan hukum nasional/daerah, harus mengabdi kepada kepentingan nasional/ daerah, dan menjadi pilar demokrasi untuk tercapainya kesejahteraan rakyat dan secara sosiologis menjadi sarana untuk tercapainya keadilan dan ketertiban masyarakat. Tujuan dari hukum yang demokratis tidak saja hanya tercapainya keadilan, akan tetapi juga terciptanya ketertiban (order). Hukum harus berfungsi menciptakan keteraturan sebagai prasyarat untuk dapat memberikan perlindungan bagi rakyat dalam memperoleh keadilan, keteraturan dan ketenangan dan bukan untuk menyengsarakannya. ${ }^{38}$

38 Pembangunan hukum nasional yang demokratis, harus meminimalisisasi pemberlakuan dan penerapan norma yang justru menimbulkan ketidakadilan, karena penerapan praktik hukum yang demikian akan menimbulkan ketidakadilan baru. 
Peneliti mengajukan teori The Integratif Law-Society Framework, sebagai model fungsionalisasi yang memiliki 3 gatra fungsional: (i) model fungsionalisasi nilai-nilai kearifan lokal dalam perumusan kebijakan hukum daerah (legal policy formulation); (ii) model fungsionalisasi nilai-nilai kearifan lokal dalam penyelenggaraan kebijakan hukum daerah (legal policy implementation); dan (iii) model fungsionalisasi nilai-nilai kearifan lokal dalam penegakan kebijakan hukum daerah sesuai cita hukum Pancasila ${ }^{39}$,sebagaimana bagan berikut.

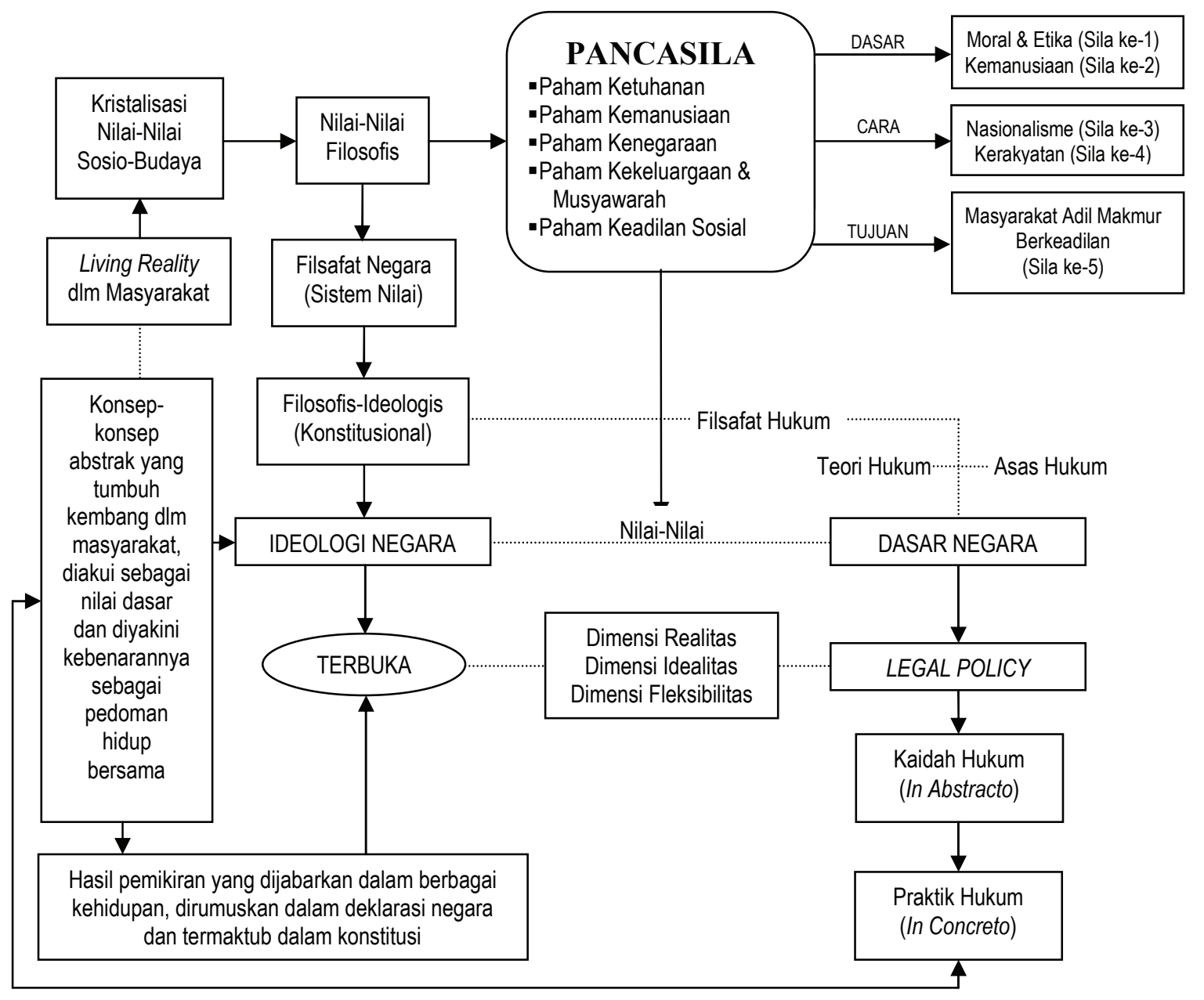

Pembangunan hukum adalah konsep yang berkesinambungan dan tidak pernah berhenti sehingga penegakan hukum tidak boleh mengabaikan keadaan dan dimensi waktu saat hukum itu ditetapkan dan berlaku. Selain tidak bijaksana, hal tersebut pada gilirannya akan berpotensi mengingkari kepastian hukum itu sendiri. Prinsip non-retroaktif itu sendiri telah digariskan di dalam Pasal 28I UUD NRI 1945 yaitu hak untuk tidak dituntut atas dasar hukum yang berlaku surut adalah hak asasi manusia yang tidak dapat dikurangi dalam keadaan apapun. Meskipun demikian, frasa 'yang tidak dapat dikurangi dalam keadaan apa pun mendapat kritik karena ada norma-norma internasional, perkecualian terhadap prinsip non-retroaktif, yaitu kejahatan-kejahatan terhadap HAM. Randang, Frankiano B. "Membangun Hukum Nasional yang Demokratis dan Cerdas Hukum". Jurnal IImiah Hukum Servanda, Vol. 3, No. 5, 2009, hlm. 3-4.

39 Cita hukum bersumber dari Pancasila yang merupakan filosofische gronslag dan common platform sebagai dasar negara. Aktivitas lembaga pembuat hukum dimuarakan pada nilai-nilai common platform tersebut yang sarat dengan budaya, nilai-nilai yang hidup dalam masyarakat atau kearifan-kearifan lokal (local wisdom) yang melekat di dalamnya. Dalam sistem hukum Pancasila, negara hukum memadukan secara harmonis unsurunsur baik dari rechtstaat (kepastian hukum) dan the rule of law (keadilan substansial). Di dalam konsepsi ini prinsip rechtstaat dan the rule of law tidak diposisikan sebagai dua konsepsi yang bersifat alternatif atau kompilatif yang penerapannya bisa dipilih berdasar selera, melainkan sebagai konsepsi yang kumulatif sebagai satu kesatuan yang saling menguatkan. MD., Moh. Mahfud. Hukum, Moral dan Politik, Melalui http://www. mahfudmd/index.php?page=web.makalahvisit\&id=2), [23/07/2014]. 
Operasionalisasi 'Integratif Law-Society Framework' sebagai model fungsionalisasi local genius dalam legal policy di bidang pengelolaan SDA dan Pelestarian $\mathrm{LH}$, harus menempatkan cita hukum Pancasila sebagai basis argumentasi. Dengan demikian, Kebijakan hukum (legal policy) bercita hukum Pancasila merupakan suatu mekanisme fungsional untuk menciptakan dan menjamin integrasi-koordinasi bangsa dan negara baik secara ideologis maupun teritorial. Efektifitas hukum dalam fungsinya untuk menciptakan integrasi sangat tergantung pada keberhasilan sistem hukum untuk menciptakan derajat stabilitas tertentu dalam proses hubungan antara sistem hukum dengan sektor-sektor lainnya.

\section{Penutup}

\section{Simpulan.}

a. Kebijakan hukum daerah (legal policy), khususnya terkait pendirian pabrik semen Gresik di Sukolilo Pati belum mengakomodasi nilai-nilai kearifan lokal (local genius) Sedulur Sikep sehingga belum dapat memberikan pengakuan, penghormatan \& perlindungan yang utuh terhadap masyarakat hukum adat (Sedulur Sikep) beserta kearifan lokalnya, baik nilai etis kehidupannya (ethics of life), maupun filosofi keselarasan dan keharmonisan (harmony), kesetaraan (egalitarianism), kebersamaan dan permusyawaratan (solidarity), kelestarian dan kesejahteraan (welfare ecology), sekaligus rasionalitas dari tindakannya terhadap lingkungan.

b. The Integratif Law-Society Framework adalah model fungsionalisasi nilainilai kearifan lokal (local genius) dalam kebijakan hukum (legal policy) daerah di bidang pengelolaan SDA dan pelestarian $\mathrm{LH}$ sesuai dengan cita hukum Pancasila. Secara teoretis, The Integratif Law-Society Framework adalah konsep kebijakan hukum reformatif yang memiliki dimensi akomodatif-deliberatif dan integratif- restoratif. Hukum reformatif adalah legal futuristic bercita hukum pancasila, yang mampu memperhitungkan kepentingan bangsa dan negara untuk kurun waktu yang panjang, jauh ke depan dengan mempertimbangkan nilai-nilai kearifan lokal yang masih hidup, sehingga dapat memperkuat fundamen ekonomi kerakyatan yang berwawasan lingkungan (ekologis), bernuansa demokratis legitimatif, integratif dan berfungsi pemulihan sosial (social recuperation). Secara operasional, The Integratif LawSociety Framework, memposisikan fungsionalisasi local genius dalam legal policy pada resiprokalitas integratif dalam perumusan dan penyelenggaraan kebijakan hukum, meliputi: (i) fungsionalisasi substansial dalam proses pembentukan hukum; (ii) fungsionalisasi struktural dalam proses penerapan hukum; dan (iii) fungsionalisasi kultural dalam proses penegakan hukum. Dengan demikian, temuan studi ini mempertegas bahwa kebijakan hukum daerah harus diarahkan pada beberapa aspek sesuai dengan rumusan masalah penelitian, yaitu: (i) Para pemegang peran (role actors) [state, stakeholders, shareholders] harus memperhatikan realitas modal sosial komunitas lokal (cq. Sedulur Sikep), berupa nilainilai kearifan lokal dalam perumusan dan penyelenggaraan legal policy (daerah) di bidang pengelolaan SDA dan pelestarian LH. Prasyarat konstitutif-harus merujuk dan tidak bertentangan dengan peraturan yang lebih tinggi-dan dimensi keadilan yang menjadi prasyarat fungsional dari suatu produk hukum, sudah tentu harus bisa terpenuhi; dan (2) Aparatur pemerintahan [eksekutif, legislative, yudikatif] baik di tingkat pusat maupun daerah provinsi/ kabupaten/kota, dapat menggunakan hasil penelitian ini berupa Teori 'The 
Integratif Law-Society Framework' sebagai model fungsionalisasi nilainilai kearifan lokal (local genius) dalam kebijakan hukum daerah di bidang pengelolaan SDA dan pelestarian $\mathrm{LH}$ sesuai cita hukum Pancasila sebagai bahan rujukan dalam menyusun dan menyelenggarakan kebijakan hukum (legal policy) di bidang pengelolaan SDA dan pelestarian LH berbasis kearifan lokal (local genius) agar sesuai cita hukum Pancasila.

\section{Saran}

a. Para pemegang peran (role actors) [state, stakeholders, shareholders] harus memperhatikan realitas modal sosial komunitas lokal (cq. Sedulur Sikep) berupa nilai-nilai kearifan lokal dalam perumusan dan penyelenggaraan legal policy (daerah) di bidang pengelolaan Sumber Daya Alam dan Pelestarian Lingkungan Hidup. Prasarat konstitutif harus merujuk dan tidak bertentangan dengan peraturan yang lebih tinggi dan dimensi keadilan yang menjadi prasyarat fungsional dari suatu produk hukum sudah tentu harus bisa dipenuhi.

b. Pemerintah Daerah, baik provinsi maupun kabupaten/kota sebagai execution actor berkewajiban untuk mengatur dan mengurus tata kelola Sumber Daya Alam dan Pelestarian Lingkungan Hidup agar dimanfaatkan sebesar-besarnya untuk meningkatkan kesejahteraan masyarakat dan mencapai kebahagian hidup berdasarkan Pancasila. oleh karena itu, perlu dilaksanakan pembangunan berkelanjutan yang berwawasan lingkungan (ekologis) yang serasi, selaras dan seimbang, melalui kebijakan hukum daerah yang terpadu dan menyeluruh dengan memperhitungkan kebutuhan generasi sekarang dan generasi yang akan datang.

\section{DAFTAR PUSTAKA}

Atmajda, Nengah Bawa, 1993, Pengelolaan Hutan Wisata Kera Sangeh oleh Desa Adat Sangeh, Dalam Ekonesia: a Journal of Indonesia Human Ecology, UI, Jakarta, Vol. 1, No. 1: 1-22.

Bagong, Suyanto dan Sutinah, 2006, Metode Penelitian Sosial Berbagai Alternatif Pendekatan, Prenada Media Group, Jakarta.

Castle, Lance dan Benda, Harry J, 1969, The Samin Movement, BKI, deel 135, 1e aflevering, Matinus Nijhoff, 'sGravenhage

Castle, Lance dan Benda, Harry J, 1969, The Samin Movement, Reprint Series, Vol. 125, No. 37. New Haven, Yale University, Southeast Asia Studies, Conn.: 207-240.

Castle, Lance dan Benda, Harry J. 1969. "The Samin Movement", Reprint Series, Vol. 125, No.

37. New Haven, Yale University, Southeast Asia Studies, Conn.: 219-222.

Galtung, Johan. 2003. Studi Perdamaian, Perdamaian dan Konflik, Pembangunan dan Peradaban, Terjemahan Asnawi dan Safruddin. Pustaka Eureka, Surabaya.

Geertz, Clifford. 1983. Local Knowledge: Further Essay in Interperatif Anthropolgy, Basic Books, New York.

Hidayat, Arief. 2006. Kebebasan Berserikat Di Indonesia (Suatu Analisis Pengaruh Perubahan Sistem Politik Terhadap Penafsiran Hukum), Badan Penerbit Universitas Diponegoro, Semarang.

http://www.bumn.go.id/semenindonesia

http://www.elsam.or.id.

http://www.mahfudmd/index.php?page=web.makalahvisit\&id=2

Hutchinson, Terry, 2002, Researching and Wraiting in Law, Pyramont-NSW. 
Hutomo, Suripan Sadi, 1985, "Samin Surontiko dan Ajaran-Ajarannya”, Basis, No.1-2, JanuariPebruari.

Jasper, J.E. Verslag Betreffende het Onderzoek in Zake de Saminbeweging Ingesteld Inge-volge het Gouvernement Besluit van 1 Juni 1917, No. 20, (Batavia, 1918).

K.Yin, Robert, 1981, Case Study Research: Desain and Methods, Sage, London.

King, Victor T, 1973, "Some Observations on The Samin Movement of The North-Central Java", $B K I$, deel 129, 4e aflevering, Matinus Nijhoff, 's-Gra-venhage: 461-463.

Kisya, Eliza, 1993, Sasi Aman Haru Ukui: Tradisi Kelola Sumberdaya Alam Lestari di Ukui, Yayasan Sejati, Jakarta.

Kleden, Ignas, 1987, Sikap IImiah dan Kritik Kebudayaan. Terjemahan F. Soesilohardo, Cetakan 1, Jakarta: LP3ES

Korver, Pieter E, 1976, "The Samin Movement and Millenarism", BKI, deel 132, 2e+3e aflevering, Matinus Nijhoff, ‘sGravenhage: 249-266.

Korver, Pieter E, 1976, "The Samin Movement and Millenarism", BKI, deel 132, 2e+3e aflevering, Martinus Nijhoff, 'sGravenhage.

Kuhn, Thomas, 2000, The Structure of Scientific Revolution. Terjemahan Tjun Surjaman, PT. Remaja Rosda Karya, Bandung.

Lampe, Munsi, 1986, Sistem Penguasaan Wilayah Perikanan dan Pemanfaatan Sumberdaya Hayati Laut Oleh Masyarakat Nelayan Bugis, Makasar Sulawesi Selatan, Depdikbud RI, Jakarta.

Lubis, Zulkifli, 1997, Repong Damar: Kajian tentang Pengambilan Keputusan dalam Pengelolaan Lahan Hutan di Pesisir Krui, Lampung Barat, CIFOR, Jakarta.

Lubis, Zulkifli, 1999, Menyelaraskan Pola dan Ruang Pengelolaan Sumberdaya Milik Bersama, USU Press, Medan.

Mangoenkoesoemo, Tjipto. Het Saminisme: Rapport Uitgebracht aan de Ver-eeniging Insulinde, (Semarang, 1918).

Meida, Avid Nur, Purwoko dan Setyono, Budi. 2013. "Konflik Corporate vs. Society: Analisis terhadap Konflik dalam Kasus Pendirian Pabrik Semen di Kecamatan Sukolilo Kabupaten Pati”. Dalam Journal of Politic and Government Studies, Vol. 2, No. 2: 123-132.

Muhadjir, Noeng, 2002, Metodologi Penelitian Kualitatif, Penerbit Rake Sarasin, Yogyakarta.

Mulder, Niels, 1974, "Saminisme and Budhisme: A Note on Field Visit to a Samin Community", Asian Quarterly, No. 3: 72-84.

Onghokham, 1964, Saminisme: Tindjauan Sosial Ekonomi dan Kebudajaan Pada Gerakan Tani Dari Awal Abad Ke-XX, Djambatan, Djakarta.

Orlove, Benjamin, 1980, "Ecological Anthropology", Annual Review in Anthropology, Vol. 9, Redgrave Publishing Company, USA: 235-273.

Peluso, Nancy Lee, 1992, Rich Forest Poor People: Resource Control and Resistance in Java, University of California Press, New York.

Rahardjo, Satjipto, 2000, "Pembangunan Hukum di Indonesia dalam konteks Situasi Global". Dalam Khudfaizah Dimyati (Penyunting), Problema Globalisasi Perspektif Sosiologi Hukum, Ekonomi dan Agama, Muhammadiyah Press, Surakarta.

Rahardjo, Satjipto, 2000, IImu Hukum, Citra Aditya Bhakti, Bandung.

Randang, Frankiano B, 2009, "Membangun Hukum Nasional yang Demokratis dan Cerdas Hukum". Jurnal IImiah Hukum Servanda, Vol. 3, No. 5: 3-4. 
Santos, Boaventura De Sousa, 1995, Toward A New Common Sense: Law, Science and Politics In Paradigmatic Transition, Routledge, New York.

Sidharta, Bernard Arif, 1989, Refleksi tentang Struktur Ilmu Hukum; Sebuah Penelitian tentang Fondasi Kefilsafatan dan Sifat Keilmuan IImu Hukum sebagai Landasan Pengembangan Ilmu Hukum Nasional Indonesia, PT Mandar Maju, Bandung.

Simarmata, Rikardo. "Socio-Legal Studies dan Gerakan Pembaharuan Hukum", Dalam Journal of Digest Law, Society \& Development, Vol. I, Desember 2006-Maret 2007.

Soekanto, Soerjono, 2007, Pengantar Penelitian Hukum, Cet.3, UI-Press, Jakarta.

Soekanto, Soerjono. dan Sri Mamudji, 1990, Penelitian Hukum Normatif: Suatu Tinjauan Singkat, Ed.1, Cet.3, Rajawali, Jakarta.

Subangun, Emmanuel, 1997, "Tidak ada Mesias dalam Pandangan Hidup Jawa". Dalam Prisma, No. 1, Januari: 26-37.

Suparmoko, M, 1997, Ekonomi Sumberdaya Alam dan Lingkungan (Suatu Pendekatan Teoritis), BPFE, Yogyakarta.

Sutrisno, Lukman, 1989, "Masalah dan Proyek PIR-BUN". Dalam Prisma No. 4 Tahun XVIII, LP3ES, Jakarta.

Widodo, Amrih, 1997, "Samin In The New Order: The Politic of Encounter and Isolation". Dalam Jim Schiller dan Barbara Martin Schiller (Penyunting), Imagining Indonesia, Cultural Politics and Political Culture, Ohio University Press, Ohio: 261-287.

Widodo, Amrih, 2000, “Untuk Hidup Tradisi Harus Mati”. Basis, September-Oktober 2000.

Widodo, Amrih, 2000, “Untuk Hidup Tradisi Harus Mati”. Basis, September-Oktober, 2000.

Wignyosoebroto, Soetandyo, 2003, "Perubahan Paradigma dalam IImu Hukum Pada Masa Peralihan Milenium: dari abad 20 ke abad 21", (Bahan Kuliah Program Doktor Ilmu Hukum UI, Jakarta). 